\title{
The Fox (Vulpes vulpes) as a Reservoir for Canine Angiostrongylosis in Denmark
}

\section{Field survey and experimental infections}

\author{
By G. Bolt, J. Monrad, P. Henriksen, H. H. Dietz, J. Koch, E. Bindseil and A. L. Jensen
}

Royal Veterinary and Agricultural University, Frederiksberg, and National Veterinary Laboratory, Århus, Denmark.

Bolt, G., J. Monrad, P. Henriksen, H. H. Dietz, J. Koch, E. Bindseil and A. L. Jensen: The fox (Vulpes vulpes) as a reservoir for canine angiostrongylosis in Denmark. Acta vet. scand. 1992, 33, 357-362. - Until recently, Angiostrongylus vasorum was not considered to be an endogenous Danish parasite, since demonstration of this worm had been confined to necropsy findings in 2 dogs, both of which had visited France. During the last 2 years, however, clinical cases have been diagnosed among a considerable number of Danish dogs, none of which had ever been outside Denmark. All these cases have occurred north of Copenhagen, where an endemic focus seems to exist. In this field survey $A$. vasorum was found for the first time in wild Danish red foxes. Furthermore, experimental infections showed that the parasite can be transferred between foxes and dogs. Consequently, the wild fox population must be considered a potential reservoir for transfer of $A$. vasorum to domestic dogs.

Angiostrongylus vasorum; experimental transfer.

\section{Introduction}

Angiostrongylus vasorum (French heartworm) is a metastrongyloid parasite of the domestic dog (Canis familiaris) and other carnivores belonging to Canidae. The adult worms parasitize in the right atrium of the heart and particularly in the pulmonary arteries. The life cycle is indirect with a number of mollusc species acting as obligatory intermediate hosts (Guilhon 1965, Guilhon 1967, Guilhon \& Cens 1973,). The pathological and clinical manifestations of canine angiostrongylosis are multiple, as reported elsewhere (Dodd 1973, Guelfi 1976, Prestwood et al. 1981, Schelling et al. 1986). The major symptoms are respiratory distress and loss of condition (Cobb \& Fisher 1990, Guelfi 1976, Koch \& Bolt 1990). The parasitological diagnosis is based on the demonstration of the characteristic first stage larvae (L1) in faecal samples analyzed by the Baermann method (Jacobs \& Prole 1975, Jørgensen \& Madsen 1982).

In Europe $A$. vasorum is known to be endemic among dogs in south-west France (Dorchies 1976, Guilhon \& Cens 1973), Ireland (Dodd 1973, Jacobs \& Prole 1975), and in south-west England (Jones et al. 1980, Simpson \& Neal 1982). Sporadic cases have been reported from other parts of France (Guilhon 1969), south-east England (Cobb \& Fisher 1990), former West Germany (Pallaske 1967), Spain (Sanchez et al. 1979), Switzerland (Eckert \& Lämmler 1972, Neff 1971), and from the European part of the former 
Sovjet Union (Eckert \& Lämmler 1972, Rosen et al. 1970). Outside Europe the parasite has been reported to be endemic among dogs in Uganda (Bwangamoi 1972), and sporadic cases have been reported from dogs in Brasil (Lima et al. 1985, Rosen et al. 1970), Columbia (Rosen et al. 1970), the United States (Williams 1985), and from the Asiatic part of the former Sovjet Union (Eckert \& Lämmler 1972). All cases reported from the United States have occurred among imported dogs.

Among foxes (Vulpes vulpes) A. vasorum has been reported from France (Guilhon 1971), Ireland (Guilhon 1971), Italy (Poli et al. 1985), Spain (Tarazona 1974), the former Sovjet Union (Eckert \& Lämmler 1972, Rosen et al. 1970), Germany (Rosen et al. 1970) and Canada (Smith \& Threlfall 1973). In Italy and France the fox is considered to be a reservoir for transmission of $A$. vasorum to domestic dogs (Guilhon 1965, Guilhon 1971, Poli et al. 1985). Guilhon succesfully transferred the parasite from dogs to 2 foxes and a jackal (Canis aureus). Patent infections were established in all 3 experimental animals (Guilhon 1965). According to our knowledge no experimental transfer from wild foxes to dogs has ever been reported.

In Denmark $A$. vasorum until recently had only been detected on necropsy of 2 dogs, both of which had visited France (Finnerup 1983, Monrad 1989). Over the last 2 years, however, clinical cases have been diagnosed in a considerable number of Danish dogs, none of which have ever been outside Denmark (Koch 1992, Koch \& Bolt 1990, Rosenlund et al. 1991). Interestingly, all these cases have occurred north of Copenhagen, where an endemic focus of yet unknown, but possibly growing extension seems to exist. This suburban region is characterized by a dense population of red foxes living in the immedi- ate vicinity of humans and their dogs. The present study was designed to examine the occurrence of $A$. vasorum in the red fox population in the locality north of Copenhagen, where the canine outbreaks had occurred. Furthermore, artificial infections were established in order to investigate, whether strains of $A$. vasorum isolated from Danish foxes and dogs might be transmissible to dogs and foxes, respectively.

\section{Materials and methods}

Examination of wild foxes

During the period October 1990 to May 1991 a total of 15 adult red foxes ( $V$. vulpes) from the above mentioned region were examined for $A$. vasorum. Of these 13 foxes were killed during hunting and can therefore be considered fairly representative of the fox population at the hunting ground, which is located in the northern outskirts of Copenhagen (Jægersborg Game Reserve). Faecal samples from all 15 foxes were subjected to the Baermann method. Hearts and lungs from some of the foxes were dissected. The right atrium and the pulmonary arteries were inspected for adult parasites, but neither gross pathological nor histopathological examinations were performed.

\section{Production of infective larvae}

L1 were isolated by the Baermann method from faeces of naturally infected foxes and dogs. The snails Biomphalaria glabrata and Helix pomatia (edible snail) were used as intermediate hosts. Experimental infection of B. glabrata, was performed by adding L1 to a beaker containing the snails according to the method described by Guilhon \& de Gaalon (1969). Experimental infection of $H$. pomatia was performed in 2 steps. Firstly, each snail was fed a small piece of lettuce contaminated with fluid containing $\mathrm{L} 1$ as 
described by Guilhon \& Afghabi (1969), and secondly, each snail was placed on a water film containing the $\mathrm{L} 1$ larvae in a beaker.

In order to demonstrate the development of infective third-stage larvae (L3), the snails were comminuted, and a proportion (10\%) of the snail tissue was digested in an $\mathrm{HCl} /$ pepsin solution at $30^{\circ} \mathrm{C}$. Slightly modified versions of the techniques described by Wallace \& Rosen (1969) were used. The L3 recovered from the snails by digestion were counted under a stereomicroscope.

\section{Infection of foxes and dogs}

The final hosts were infected by feeding them infective snail material mixed with a palatable feed. Two adult silver foxes $(V$. vulpes) originating from a fox farm were infected with L3 developed from L1, which had originally been isolated from the faeces of a dog suffering from angiostrongylosis. Fox No. 1 received approximately 250 larvae passed in $B$. glabrata and fox No. 2 approximately 100 larvae passed in $H$. pomatia. Another 2 uninfected foxes (No. 3 and No. 4), which were of the same origin as fox No. 1 and No. 2, served as non-infected controls. The faeces of all 4 foxes were examined by the Baermann method once a week.

Two 4 month old SPF beagle puppies (dog No. 1 and dog No. 2) were infected, as well. Dog No. 1 was infected with 100-200 L3 developed in $B$. glabrata from L1 isolated from the faeces of 2 wild red foxes. Dog No. 2 was infected with $300-500$ L3 developed in B. glabrata from L1 isolated from the faeces of 2 dogs suffering from angiostrongylosis. Faeces from the dogs were examined by the Baermann method twice a week.

Gross pathological lesions were noticed at necropsy of foxes and dogs, while histopathological examination of lung tissue was carried out in the dogs only.

\section{Results \\ Wild foxes}

In 12 of the 15 foxes typical A. vasorum L1 were found in the faeces, though in moderate numbers $(<150 \mathrm{~L} 1 / \mathrm{g})$. Poor blood coagulation was observed in 4 of the infected foxes. Whenever infected foxes were necropsied, adult $A$. vasorum of both sexes were found in the right atrium of the heart and in the pulmonary arteries. Few worms were found in each fox, and all foxes appeared to be in good bodily condition, indicating that the infection was of minor significance to the foxes. Another 2 helminth species, Crenosoma vulpis and Capillaria aerophila, were found in 8 and 2 of the foxes, respectively.

\section{Experimental infection of foxes}

In the faeces from fox No. 1 and fox No. 2 excretion of $A$. vasorum $\mathrm{L} 1$ started 52 and 55 days post infection, respectively. The foxes were euthanized 74 days post infection. At that time the faeces of fox No. 1 and fox No. 2 contained $153 \mathrm{~L} 1 / \mathrm{g}$ and $1.5 \mathrm{~L} 1 / \mathrm{g}$, respectively. No clinical symptoms were noticed during the course of infection. At necropsy gross pathological lesions comparable to those described for naturally infected foxes (Poli et al. 1985) and experimentally infected dogs (Neff 1971, Prestwood et al. 1981) were found in the lungs of both foxes. A total of 52 adult worms ( 28 females and 24 males) were found in fox No. 1, whereas a total of 8 adult worms (5 females and 3 males) were found in fox No. 2. The faeces of fox No. 3 and fox No. 4 did at no time contain larvae, and no worms were found post mortem in these 2 foxes.

\section{Experimental infection of dogs}

In the faeces from dog No. 1 and dog No. 2 excretion of $A$. vasorum L1 started 56 and 52 days post infection, respectively. The dogs 
were euthanised 135 days post infection, as dog No. 2 was exhibiting mild symptoms of a circulatory disorder. At that time the faeces of dog No. 1 and dog No. 2 contained 5,760 $\mathrm{L} 1 / \mathrm{g}$ and $12,480 \mathrm{~L} 1 / \mathrm{g}$, respectively. At necropsy gross pathological and histopatological lesions comparable to those described for other experimentally infected dogs (Neff 1971, Prestwood 1981) were found in both dogs. A total of 43 adult worms (24 females and 19 males) were found in $\operatorname{dog}$ No. 1 , whereas a total of 437 adult worms (289 females and 148 males) were found in dog No. 2.

\section{Discussion}

It appears that this was the first time for $A$. vasorum to be observed in wild Danish foxes, since this parasite was not detected in the only parasitological survey of wild foxes, previously reported from Denmark (Guildal \& Clausen 1973). When and how the infection was introduced into the wild Danish fox population remains unknown, however. In Denmark even the first canine angiostrongylosis case was observed within recent years (Finnerup 1983). Being a conspicuous worm parasite, it seems most unlikely that $A$. vasorum would be overlooked in a country like Denmark for many decades.

However, the mere detection of $A$. vasorum in wild foxes originating from an area enzootic of canine angiostrongylosis would be of little value. Thus, certain nematode parasite strains isolated from wild deer have proved incompatible to cattle, although another natural strain of the same worm species is found in cattle (Korsholm 1988). Theoretically, something similar might apply to fox and dog strains of $A$. vasorum, for which reason, our successful experimental transfer of a fox strain of $A$. vasorum to dogs and vice versa was of great importance. Thus, it was proved that this parasite may be transmitted between Danish foxes and dogs. In particular our experimental transfer from fox to dog must be considered the first proof of the fact that a fox population may serve as a reservoir for transmission of $A$. vasorum to domestic dogs.

No explanation can be given, so far, as to the uneven geographic distribution of $A$. vasorum among dogs, a distribution which is characterized by enzootic occurrence in some isolated regions and sporadic cases in others. Eckert \& Lämmler (1972) proposed that $A$. vasorum is a common parasite among wild carnivores, from which it is only occasionally transmitted to the dog population. Here it can be maintained under favourable conditions, including a high density of the intermediate host population, resulting from mild winters and high air humidity. Indeed, the latest 3 winters have been exceptionally mild in Denmark.

The finding of a high incidence of low grade infections among wild foxes, which seemed unaffected by the infection, indicates a considerable degree of adaptation between $A$. vasorum and the fox. In combination with the finding that $A$. vasorum can be transmitted between foxes and dogs, and the fact that all known cases of canine angiostrongylosis in Denmark have occured in a region with a dense suburban fox population, suggests that foxes could be a reservoir of epidemiological importance, particularly in such areas with close coexistence of foxes and dogs.

\section{Acknowledgements}

This study was supported by a grant from the Special Fund for Basic Research at the Royal Veterinary and Agricultural University. T. Christiansen, ranger, Jægersborg Forest District, is acknowledged for providing fox material from Jægersborg Game Reserve. Dr. N. Wøldiche Pedersen, Gentofte Veterinary Clinic, kindly provided contact to the owner 
of an infected dog. Thanks are due to K. Madsen, M. Pearman, and M. Sørensen for technical laboratory assistance, and to The Danish Bilharziasis Laboratory, Charlottenlund, for rearing of Biomphalaria snails. We are also grateful to $\mathrm{H}$. J. Petersen, Helix Farm, for providing Helix snails.

\section{References}

Bwangamoi $O$ : Angiostrongylus vasorum and other worms in dogs in Uganda. Vet. Rec. 1972, 91, 267.

Cobb MA, Fisher MA: Angiostrongylus vasorum: Transmission in south-east England. Vet. Rec. 1990, 126, 529.

Dodd K: Angiostrongylus vasorum (Baillet 1866) Infestation in a Greyhound kennel. Vet. Rec. 1973, 92, 195-197.

Dorchies P: Étude zoologique d'Angiostrongylus vasorum. (Zoological studies of Angiostrongylus vasorum). Anim. Compagnie. 1976, 11, 4548.

Eckert J, Lämmler G: Angiostrongylose bei Mensch und Tier. (Angiostrongylosis in humans and animals). Z. Parasitenkd. 1972, 39, 303-322.

Finnerup E: Angiostrongylus vasorum hos hund, En oversigt og en kasuistik. (Canine angiostrongylosis, a review and a case story). Dansk VetTidsskr. 1983, 66, 338-340.

Guelfi JF: Symptômes et diagnostic de la strongylose cardio-pulmonaire du chien. (Symptoms and diagnostics of canine cardio-pulmonary strongylosis). Anim. Compagnie 1976, 11, 49-56.

Guildal JA, Clausen B: Endoparasites from one hundred Danish red foxes (Vulpes vulpes (L.)). Norweg. J. Zool. 1973, 21, 329-330.

Guilhon J: Transmission d'Angiostrongylus vasorum (Baillet 1866) aux Canides sauvages. (Tranfer of Angiostrongylus vasorum to wild Canidae). CR. Acad. Sci. (Paris), 1965, 261, Groupe 12, 4496-4497.

Guilhon J: Spécificité d'Angiostrongylus vasorum (Baillet 1866). (Specificity of Angiostrongylus vasorum). Helminthologia, 1967, 8, 171-172.

Guilhon J: Angiostrongylose canine et incidences sur la santé humaine. (Canine angiostrongylosis and influence on human health). Bull. Soc. Path. exot. 1969, 62, 411-421.

Guilhon J: Rôle des animaux dans l'étiologie et l'épidemiologie de nouvelles zoonoses: les angiostrongyloses. (The importance of animals to the etiology and epidemiology of the new zoonoses: the angiostrongyloses). Bull. Acad. nat. Med. 1971, 155, 223-232.

Guilhon J, Afghabi A: Évolution larvaire d'Angiostrongylus vasorum (Baillet 1866) dans l'organisme de diverse espèces de mollusques terrestres. (The larval development of Angiostrongylus vasorum in various terrestrial snails). CR. Acad. Sci. [D] (Paris). 1969, 268, 434-436.

Guilhon J, Cens B: Angiostrongylus vasorum (Baillet, 1866) Etude biologique et morphologique. (Biological and morphological studies of Angiostrongylus vasorum). Ann. Parasitol. Hum. Comp. 1973, 48, 567-596.

Guilhon J, de Gaalon A: Evolution larvaire d'un nématode parasite de l'appareil circulatoire du chien dans l'organisme de mollusques dulcaquicoles. (The larval development in fresh water snails of a canine cardio-vascular nematode parasite). CR. Acad. Sci. [D] (Paris). 1969, 268, 612-615.

Jacobs DE, Prole JHB: Angiostrongylus vasorum and other nematodes in British greyhounds. Vet. Rec. 1975, 96, 180.

Jones GW, Neal C, Turne, GRJ: Angiostrongylus vasorum infection in dogs in Cornwall. Vet. Rec. 1975, 106, 83.

Jørgensen RJ, Madsen $K$ : Unders $\emptyset$ gelse af fæcesprøve for lungeormlarver. (Examination of fecal samples for lungworm larvae). Dansk VetTidsskr. 1982, 65, 517-518.

Koch J: Unpublished results. 1992.

Koch J, Bolt G: Angiostrongylus vasorum hos hund. (Canine angiostrongylosis). Dansk VetTidsskr. 1990, 73, 1239-1243.

Korsholm H: Nematodinfektioner hos råvildt og kvæg. Belysning af reservoirværtsproblematikken. (Nematode infections in roe deer and cattle - analysis of the reservoir host problems). Ph.D. Thesis, Royal Veterinary and Agricultural University, Copenhagen. 1988.

Lima W, Dos S, Costa $H M$ de A, Guimaraes $M P$ Leite, ACR: Angiostrongylus vasorum (Baillet 1866) Nematoda: protostrongylidae, Em caes de Minas Gerais, Brasil. (A case of Angiostrongylus vasorum in the State of Minas Gerais, Brazil). Mem. Inst. Oswaldo Cruz 1985, 80, 233-235.

Monrad J: Unpublished results. 1989.

Neff $H$ : Experimentelle Infektionen von Hunden mit Angiostrongylus vasorum. (Experimental infections of dogs with Angiostrongylus vasorum). Inaugural-Dissertation. Univ. Zürich. 1971. 
Pallaske G: Zur Angiostrongylose des Hundes. (Canine angiostrongylosis). Dtsch. tierärztl. Wschr. 1967, 74, 166-171.

Poli A, Arispici M, Marconicini A, Mancianti F, Corsi $C$ : Lungworms in red foxes (Vulpes vulpes) from the maritime provinces of Tuscany. In: Erkrankungen der Zootiere. Verhandlungsbericht des 27. Internationalen Symposiums über die Erkrankungen der Zootiere, 9-13 Juni, St. Vincent/Torino. Akademie Verlag, Berlin, 1985, 507-512.

Prestwood AK, Greene CE, Mahaffey EA, Burgess $D E$ : Experimental canine angiostrongylosis: I. Pathologic manifestations. J. Amer. Anim. Hosp. Assoc. 1981, 17, 491-497.

Rosen L, Ash LR, Wallace GD: Life history of the canine lungworm Angiostrongylus vasorum (Baillet). Amer. J. vet. Res. 1970, 31, 131-143.

Rosenlund P, Boserup F, Monrad J: Angiostrongylus vasorum i forreste $\varnothing$ jenkammer hos hund: (Angiostrongylus vasorum in the anterior chamber of the eye of a dog) Dansk VetTidsskr. 1991, $71,451-453$.

Sanchez Acedo C, Badiola Diez J, Graus Morales J, Cuervo Menendez L, Castillo Hernandez JA, Garcia de Jalon JA: Angiostrongylosis canina. (Canine angiostrongylosis). Rev. Iber. Parasitl. 1979, 39, 135-142.

Schelling CG, Greene CE, Prestwood AK, Tsang $V C W$ : Coagulation abnormalities associated with acute Angiostrongylus vasorum infection in dogs. Amer. J. vet. Res. 1986, 47, 2669-2673.

Simpson KR, Neal C: Angiostrongylus vasorum infection in dogs and slugs. Vet. Rec. 1982, 111, 303-304.
Smith FR, Threlfall W: Helminths of some mammals from New Foundland. Amer. Midl. Nat. 1973, 90, 215-218.

Tarazona JM: Helminthos parasitos de vertebrados de vida silvestre de la provincio de Huesca. (Helminth parasites of wild vertebrates of the Huesca Province, Spain). An. Inst. Nac. Invest. Agrar. Ser. Hig. Sanid. Anim. 1974, 1, 161-165.

Wallace GD, Rosen $L$ : Techniques for recovering and identifying larvae of Angiostrongylus cantonensis from molluscs. Malacologia. 1969, 7, 427438.

Williams JF: Angiostrongylosis in a Greyhound. J. Amer. vet. Med. Assoc. 1985, 186, 1101-1103.

\section{Sammendrag \\ Feltundersøgelser og eksperimentelle infektioner til belysning af vildraven (Vulpes vulpes) som reser- voir for angiostrongylose hos hunde i Danmark.}

I Danmark havde Angiostrongylus vasorum indtil for få år siden kun været påvist ved sektion af to danske hunde, som begge havde været i Frankrig forinden. Inden for de sidste to år er imidlertid konstateret et betydeligt antal kliniske tilfælde hos danske hunde, som aldrig har været i udlandet. Alle disse tilfælde er forekommet nord for København, hvor et endemisk focus synes at eksistere. Ved feltundersøgelser påvistes $A$. vasorum for første gang hos danske ræve. Ved eksperimentelle infektioner blev det bekræftet, at parasitten kan overføres mellem ræve og hunde. Rævebestanden i det endemiske focus må derfor betragtes som et potentielt reservoir for smitte til hunde.

(Received June 19, 1992; accepted August 26, 1992).

Reprints may be requested from: J. Monrad, Department of Veterinary Microbiology, The Royal Veterinary and Agricultural University, Bülowsvej 13, DK-1870 Frederiksberg C, Denmark. 